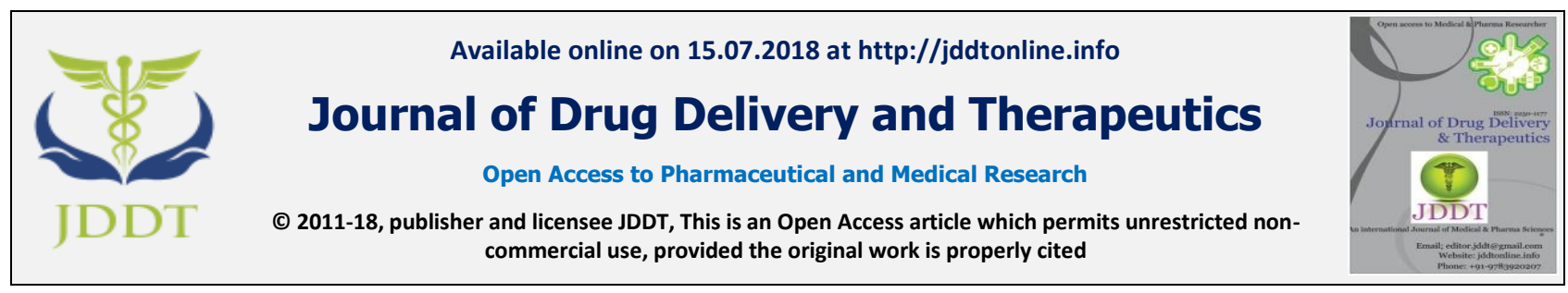

Open $\odot$ Access

Research Article

\title{
PHYTOCHEMICAL CHARACTERIZATION AND ANTIOXIDANT ASSESSMENT OF HERBAL EXTRACTS
}

\author{
Suresh Kumar Dev*, Pratim Kumar Choudhury, Rajnish Srivastava, Maya Sharma \\ Department of Pharmaceutical Science, Mohan Lal Sukhadia University, Udaipur, Rajasthan, India
}

\section{ABSTRACT}

Aim: The present study was aimed to evaluate and compare the antioxidant potential of the methanolic extracts Plumbago zeylanica Linn (PZME), Datura stramonium (DSME) and Argemone mexicana Linn (AMME) with its polyherbal methanol extract (PHME) composition.

Material and method: All the extracts were screened for the presence of various phytochemical by known and standard methods. Qualitative estimation of some potential phytoconstituents like flavonoids and polyphynolics was characterized by TLC (thin layer chromatography) and FTIR (Fourier Transform Infrared Spectroscopy). The quantification of the Rutin (flavonoid) and Gallic acid (polyphenol) were carried out using UV-visible spectrophotometry. The antioxidant activity of methanolic plant extracts and their combinations were assessed by DPPH (1, 1-diphenyl-2-picryl-hydrazil) method. Ascorbic acid was used as a standard and the antioxidant potential were evaluated at 2, 4, 6 and $8 \mathrm{mg} / \mathrm{ml} \mathrm{concentration.}$

Results: The phytochemical characterization of PZME, DSME and AMME revealed the presence of tannins, alkaloids, phenols and flavonoids.The polyherbal methanol extract (PHME) was found to exhibit potent antioxidant activity with maximum free radical scavenging activity (FRSA) of $82.79 \%$ as compared to standard ascorbic acid (92.92\%) at a concentration of $8 \mathrm{mg} / \mathrm{ml}$ and was found to be significantly greater than individual methanol plant extracts.

Conclusion: The study revealed a potent synergistic antioxidant effect of methanol extracts of Plumbago zeylanica Linn, Datura stramonium Linn and Argemone mexicana Linn which can be successfully used to mitigate oxidative stress associated complications and other regenerative therapies.

Keywords: Plumbago zeylanica Linn, Datura stramonium Linn, Argemone mexicana Linn, Antioxidant, DPPH (1, 1-diphenyl-2picryl-hydrazil), FTIR, Rutin, Gallic acid.

Article Info: Received 03 March, 2018; Review Completed 24 May 2018; Accepted 26 May 2018; Available online 15 July 2018

Cite this article as:

Dev SK, Choudhury PK, Srivastava R, Sharma M, Phytochemical characterization and antioxidant assessment of herbal extracts, Journal of Drug Delivery and Therapeutics. 2018; 8(4):126-133 DOI: http://dx.doi.org/10.22270/jddt.v8i4.1736

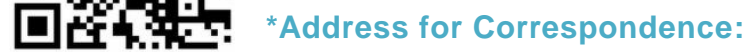

Suresh Kumar Dev, Department of Pharmaceutical Science, Mohan Lal Sukhadia University, Udaipur, Rajasthan, India

\section{INTRODUCTION}

The oxidative environment presents a range of free radicals like superoxide, hydroxyl radical, nitric oxide and peroxynitrite, for interaction with living organisms. These are the evidences that these free radicals cause various diseases like Cancer, neuro-degeneration and some inflammatory disease ${ }^{\mathbf{1 - 2}}$. It has been reported as an inverse relationship between antioxidative status and incidence of human diseases such as cancer, aging, neurodegenerative disease, and atherosclerosis ${ }^{3}$. Antioxidants have therefore gained importance in recent times for their capacity to neutralize free radicals. The plants produce significant number of antioxidants to prevent the oxidative stress caused by photons and oxygen thus can be a potential source for newer compounds with antioxidant activity.

Argemone mexicana Linn (Family Papaveraceae) known as Ghamoyais an exotic weed indigenous in South America, but has widespread distribution in many tropical and sub-tropical countries including West Africa. It is considered as an important medicinal plant in India. The yellow juice, which exudes when the plant is injured, has found usage as traditional medicine in India for dropsy, jaundice, ophthalmia, scabies and cutaneous infections. Its various parts have been used in chronic skin diseases, emetic, expectorant, demulcent 
and diuretic, while its seeds and seed oil have been used for the treatment of dysentery, ulcers, asthma and other intestinal infections ${ }^{4}$.

Datura stramonium Linn., a wild-growing plant belonging to the Solanaceae family, is widely distributed and easily accessible worldwide. It contains a variety of toxic tropane alkaloids such as atropine, hyoscamine, and scopolamine and has been used in Ayurveda for curing various ailments like ulcers, wounds, inflammation, rheumatism, gout, sciatica, bruises, swellings, fever, asthma, bronchitis and toothache. Previous studies have revealed pharmacological effects of this plant, however, complete information regarding its pharmacology, toxicity, ethnobotany and phytochemistry still remain ${ }^{\mathbf{5}}$.

Plumbago zeylanica Linn. is commonly known as white chitraka, belonging to the family plumbaginaceae. It is distributed as a weed throughout the tropical and subtropical countries of the world. It is a perennial subscandent shrub, growing throughout India, especially in Bengal, Uttar Pradesh, Kerala, Andhra Pradesh, Karnataka and Sri Lanka in most places. Traditionally it is used as a stimulant, digestant, expectorant, laxative, abortifacient and also in the treatment of muscular pain and rheumatic disease ${ }^{6}$.

The usefulness of the pharmacologically active ingredients of the Ayurvedic medicines has been established. The phytochemical constituent in the herbals such as saponins, tannins, alkaloids, alkenyl phenols, flavonoids, terpenoids, phorbol esters and sesquiterpenes lactones have desired healing effects. A single herb containing more than one of the phytoconstituents, works synergistically producing the derived pharmacological action ${ }^{7}$.

The polyherbalism offers more benefits as compared to a single herbal formulation and the derived therapeutic effect can be achieved with a single multi-constituent formulation. The lower dose of such herbal preparations would lead to reduced risk of deleterious side effects and multi drug dosing. These benefits have escalated the popularity of polyherbalism in the market as compared to a single herbal formulation. Based on these assumptions the present study was under taken to investigate and compare the antioxidant potential of the methanol extracts of Plumbago zeylanica Linn, Datura stramonium Linn and Argemone mexicana Linn. with their polyherbal compositions.

\section{MATERIAL AND METHOD}

\section{Plant collection and authentication}

The stem, leaf and aerial parts of Plumbago zeylanicaLinn, Datura stramonium Linn and Argemone mexicanaLinn respectively, were collected in the month of November from Mohanlal Sukhadia University campus, Udaipur, Rajasthan, India. Plant materials were identified and authenticated by the Botanical Survey of India, Arid Zone Regional Centre, Ministry of Forest and Climate Change, Jodhpur, Rajasthan, India.

\section{Extraction}

The extraction was individually carried out for different selected plants. The plant materials were shade-dried for 2 weeks, pulverized to a coarse powder, and passed through a sieve 20 to maintain uniformity. The coarsely dried powder was first treated with petroleum ether (60$80{ }^{\circ} \mathrm{C}$ ) for $24 \mathrm{hrs}$ to remove fatty materials and then reextracted by methanol and using soxhlet apparatus at predefined temperatures ${ }^{8-10}$. The extract was collected, filtered through Whatman filter paper, and concentrated in vacuum under reduced pressure. The dried extracts (Plumbago zeylanica Linn methanol extract: PZME, Datura stramonium Linn methanol extract: DSME and Argemone mexicana Linn methanol extract: AMME) were stored at $4 \mathrm{OC}$ for further study.

\section{Phytochemical testing}

The individual (PZME, DSME and AMME) as well as polyherbal methanol extract (PHME) were subjected to various phytochemical screening tests for the identification of the phytoconstituents present by using standardized procedures ${ }^{11}$.

\section{Fourier Transform Infrared (FTIR) Spectroscopy}

FTIR (Bruker Spectrometer, Germany) analysis of the PZME, DSME and AMME were performed and the spectrum was recorded in the range of $4000-400 \mathrm{~cm}^{-1}$ at a resolution of $4 \mathrm{~cm}^{-1}$.

\section{Estimation of Gallic acid and Rutin Content}

The Gallic acid and Rutin content were determined by a standardized method with some modifications ${ }^{\mathbf{1 2}}$.

A stock solution of Gallic acid $(100 \mu \mathrm{g} / \mathrm{ml})$ was prepared in $50 \%$ methanol from which dilutions of 5, 10, 15, 20, 25,30 and $35 \mu \mathrm{g} / \mathrm{ml}$ were prepared. The methanol test extract $(1 \mathrm{gm})$ was dissolved in $100 \mathrm{ml}$ of methanol $(50 \%)$.The absorbance of the Gallic acid and test sample were measured by UV spectrophotometer (Schimadzu, Japan) at $\lambda \max$ of $272 \mathrm{~nm}$ against distilled water as blank. Quantification of Gallic acid was done from a standard curve as percentage w/w Gallic acid content.

Rutin $(10 \mathrm{mg}$ ) was dissolved in $10 \mathrm{ml}$ of methanol $(80 \%)$ and then serial dilution of $10,20,30,40$ and 50 $\mathrm{mg} / \mathrm{ml}$ was prepared. About $100 \mathrm{mg}$ of methanol extract was dissolved separately in $100 \mathrm{ml}$ of methanol $(80 \%)$. The absorbance of the sample was measured at $260 \mathrm{~nm}$ using UV spectrophotometer, taking distilled water as blank. Quantification was done on the basis of the standard curve of Rutin. Results were expressed as percentage w/w Rutin content.

\section{Qualitative estimation of phytoconstituents by thin layer chromatography (TLC)}

Thin layer chromatography was performed using standard methods (Harborne, 1998). Samples PZME, DSME and AMME $(2 \mathrm{mg} / \mathrm{ml})$ were dissolved in methanol. Solvent systems, developed by varying the concentration of mobile phases were used. The plates were visualized directly after drying and with the help of UV-TLC viewer (Figure 1). The $R f$ value of the different spots so obtained were calculated and these values were matched with the reference values ${ }^{\text {13-15. }}$. 

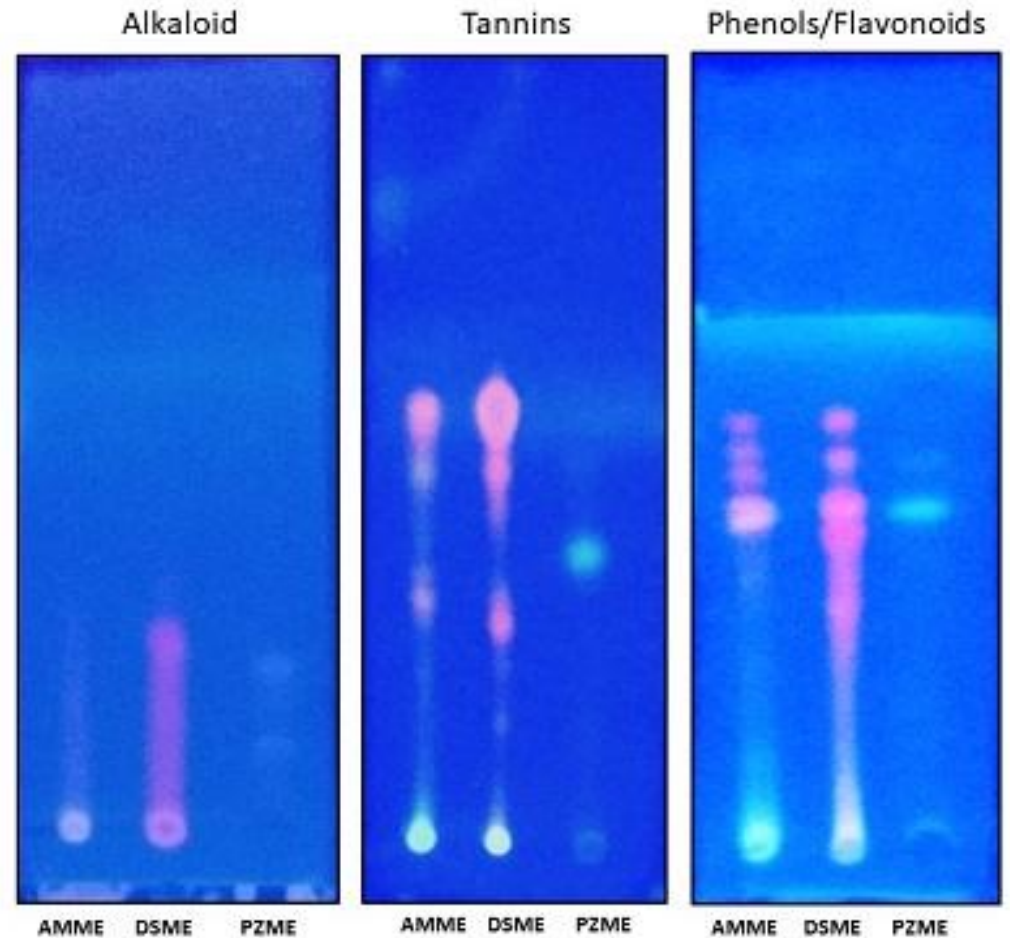

Figure 1: TLC of methanol extracts for alkaloids, tannins and phenolic/flavonoid compound characterization.

\section{Development of Polyherbal Composition}

The polyherbal formulation consists of combination of PZME, DSME and AMME. In case of phytochemical screening, equal proportions of the above extracts were taken, however the proportion of individual extract for polyherbal composition was decided on the basis of its individual in-vitro efficacy i.e. percentage free radical scavenging activity. The order of the antioxidant activity of methanol extracts was found to be in the order of PZME $>$ AMME $>$ DSME. Hence the proportion of the extracts was taken in the order of 5:3:2.

\section{In-vitro antioxidant activity of poly herbal methanol extract (PHME) by DPPH method}

The free radical scavenging activity of the individual extract as well as poly-herbal combination was measured by standardized 1, 1-diphenyl-2-picrylhydrazil (DPPH) method with some modifications ${ }^{\mathbf{1 6}}$. DPPH solution $(0.1 \mathrm{mM})$ was prepared in methanol. Higher concentrations of DPPH will show the absorbance beyond the accuracy of spectrophotometric measurement ${ }^{17-18}$, so the concentration of DPPH was so chosen such that it obeys beer's lambert laws. From the stock solution $(10 \mathrm{mg} / \mathrm{ml})$ of ascorbic and methanol extract test samples (PZME, DSME, AMME and PHME), serial dilution of 2, 4, 6 and $8 \mathrm{mg} / \mathrm{ml}$ concentration were prepared. To $50 \mu$ l of test sample of different concentration, $1 \mathrm{ml}$ of DPPH solution $(0.1 \mathrm{mM})$ was added in each test tube. The final volume in each test tube was made up to $3 \mathrm{ml}$ with methanol. The reaction mixture was shaken vigorously and allowed to stand at room temperature for 30 minutes. Absorbance of the resulting mixture was measured at $517 \mathrm{~nm}$ against methanol as blank using a UV-visible spectrophotometer. Each sample was measured in triplicate and the results were represented as mean. The ascorbic acid was used as a standard antioxidant in this method. Percentage of DPPH free radical scavenging activity (FRSA) was determined as follows:

$\%(F R S A)$

$=\frac{(\text { Absorbance of control }- \text { Absorbance of test sample })}{\text { Absorbance of control }} \times 100$

The absorbance of DPPH was found to decrease by an exposure to light because of changes in its magnetic property so the procedures were carried out in a dark chamber (Figure 2). Standardized precautionary methods were adopted to prevent changes in the magnetic properties of the DPPH especially during the working and storage. A freshly prepared DPPH solution in methanol, stored under ambient laboratory temperature $\left(24-25^{\circ} \mathrm{C}\right)$ in the dark was utilized within 24 hours ${ }^{19}$. 

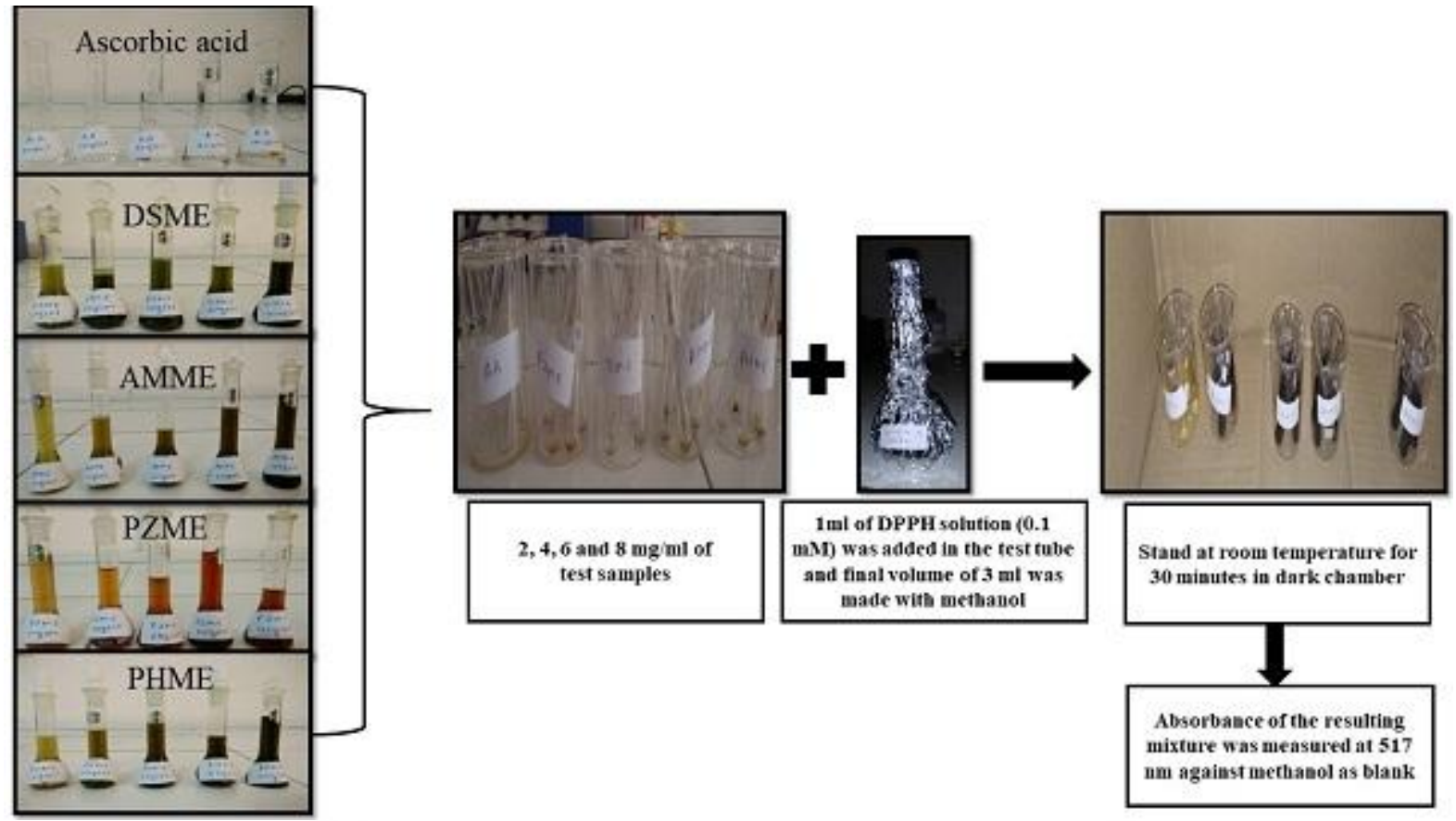

Figure 2: Scheme of in-vitro antioxidant DPPH method

\section{RESULT}

Phytochemical investigation of PZME, DSME and AMME revealed the presence of diverse phytoconstituents.

\section{Table 1: Preliminary phytochemical screening of different methanol plant extracts}

\begin{tabular}{|c|c|c|c|c|}
\hline \multirow{2}{*}{ Phytoconstituents } & \multicolumn{4}{|c|}{ Inference } \\
\cline { 2 - 5 } & PZME & DSME & AMME & PHME \\
\hline Triterpenoids & + & + & + & + \\
\hline Tannins & + & + & + & + \\
\hline $\begin{array}{c}\text { Steroids and } \\
\text { sterols }\end{array}$ & + & + & + & + \\
\hline Saponins & + & + & + & + \\
\hline Proteins & + & + & + & + \\
\hline Glycosides & + & + & + & + \\
\hline Flavonoids & + & + & + & + \\
\hline Carbohydrates & + & + & + & + \\
\hline Alkaloids & + & + & + & + \\
\hline \multicolumn{7}{|c|}{}
\end{tabular}

Plus (+) = Present, Minus (-) = Absent
The phytochemical screening showed that these plants extract after being incorporated as polyherbal (PHME) does not have any impact on its phytocomposition and was found to possess all phytoconstituents as shown by other methanol extract (Table 1).

\section{FTIR analysis}

FTIR analysis was carried out to characterize methanolic extract obtained from each plant as shown in figure-3,4 and 5. It has been observed that PZME, AMME and DSME showed a characteristic peak of the carbonyl absorption band at $1653.61 \mathrm{~cm}^{-1}, 1603.51 \mathrm{~cm}^{-1}$ and $1660.03 \mathrm{~cm}^{-1}$ respectively which is assigned to aromatic ketonic carbonyl stretching which corresponds to the presence of flavonoids. Characteristics peaks at 3408.82 $\mathrm{cm}^{-1}, 3143.23 \mathrm{~cm}^{-1}$ and $3409.99 \mathrm{~cm}^{-1}$ of PZME, AMME and DSME respectively are due to hydroxyl stretching of alcohols and phenols of the flavonoids.

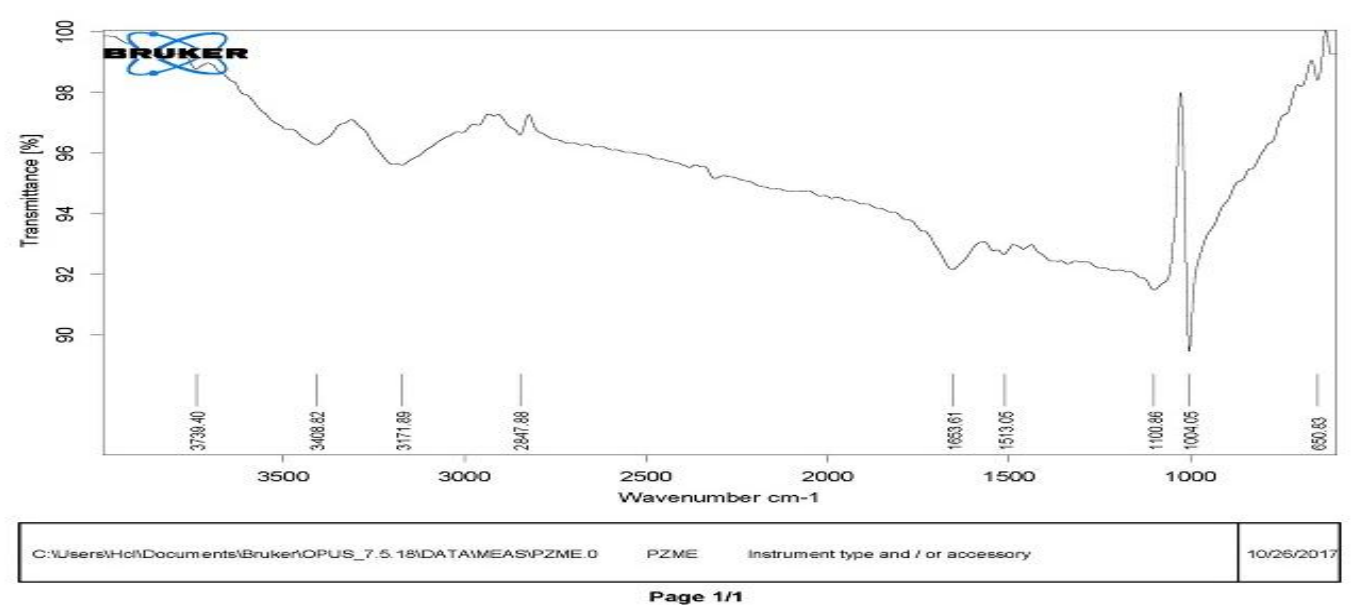

Figure 3: FTIR spectrum of Plumbago zeylanica Linn methanol extract (PZME) 


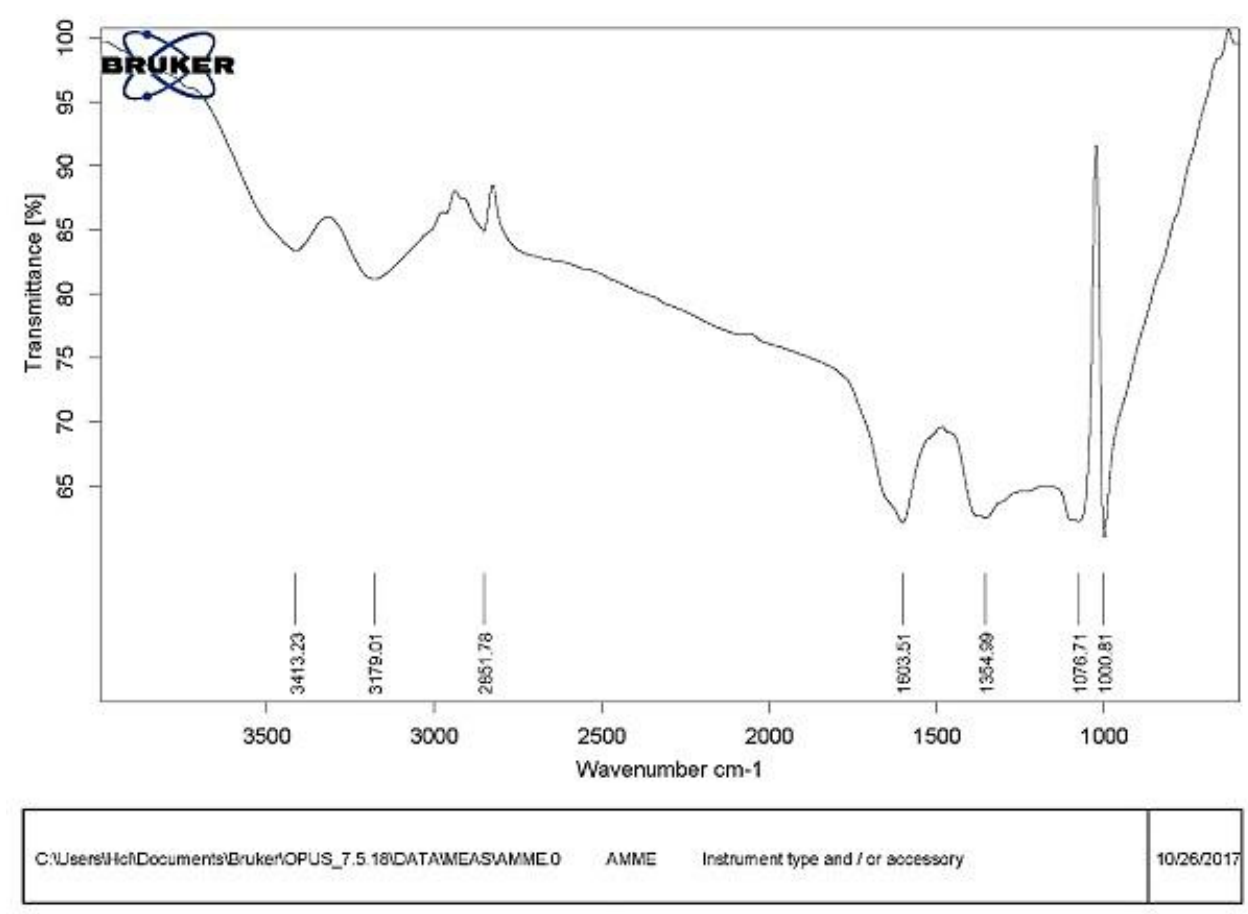

Figure 4: FTIR spectrum of Argemone Mexicana Linn methanol extract (AMME)

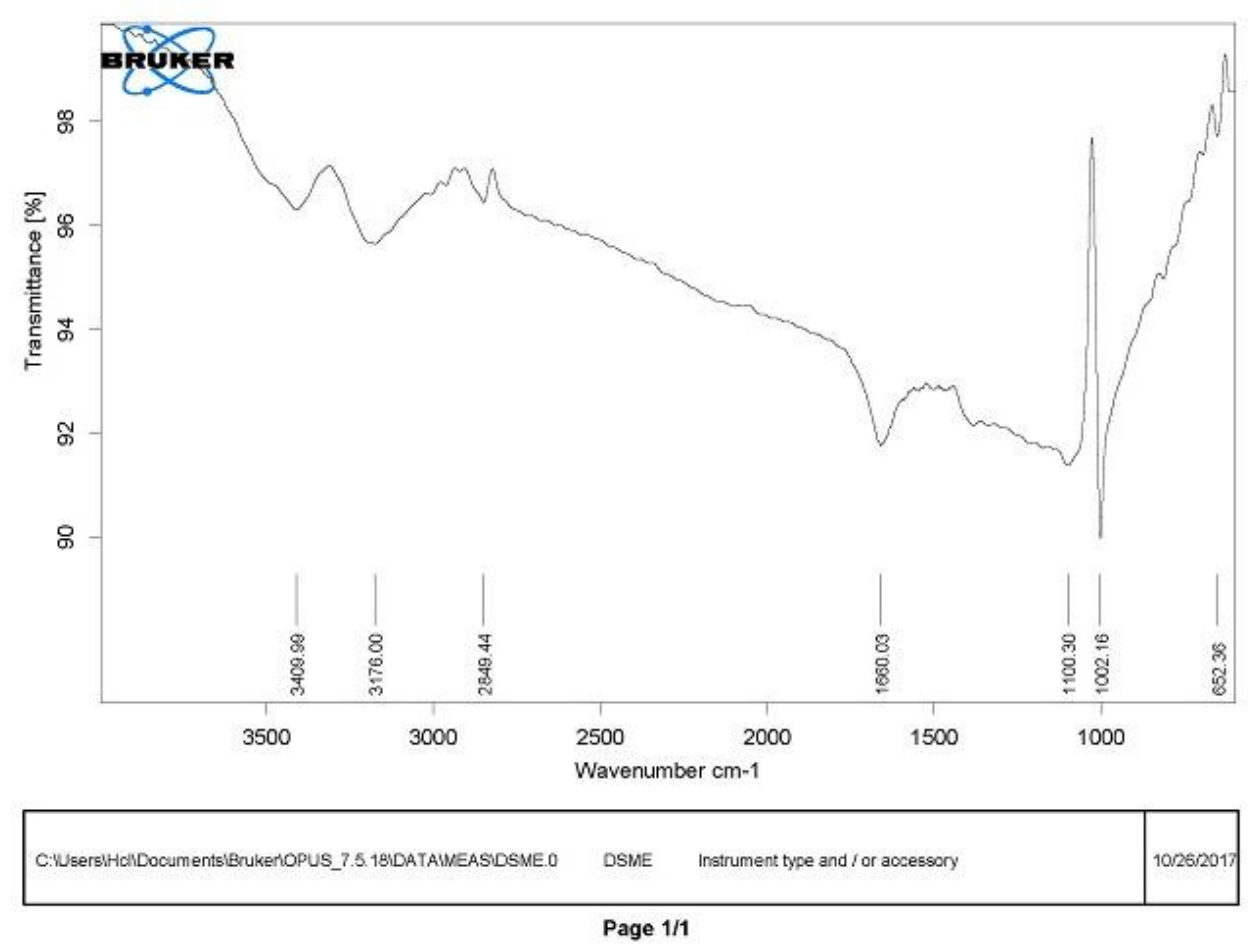

Figure 5: FTIR spectrum of Datura stramonium Linn methanol extract (DSME)

\section{Gallic acid and Rutin content}

The percentage of Gallic acid contents for PZME, AMME and DSME was found to be $7.58 \pm 1.53 \%, 7.39$ $\pm 1.98 \%$, and $9.18 \pm 1.41 \% \mathrm{w} / \mathrm{w}$ respectively. The Rutin content for PZME, AMME and DSME was found to be $3.55 \pm 1.52 \%, 10.30 \pm 1.84 \%$ and $13.26 \pm 1.65 \% \mathrm{w} / \mathrm{w}$ respectively.

\section{Thin layer chromatography of methanolic extracts}

The $R f$ values obtained from PZME, DSME and AMME revealed the presence of alkaloids, tannins and phenols/ flavonoids. The $R f$ values obtained were matched with the standards and an inference was summarized in Table 2. The DSME revealed presence of tannins (4 spots) and flavonoids/phenolic compound (5 spots).7-hydroxy flavone, Ferulic acid, 6-Hydroxy flavones and 6Hydroxy flavones derivatives were inferred as phenolic and flavonoid compound. Similarly, cinnamic acid derivatives, Ferulic acid and paragallol were inferred as tannins based on their $R f$ values. 
Table 2: $R_{f}$ values of samples by TLC

\begin{tabular}{|c|c|c|c|}
\hline \multicolumn{4}{|c|}{ Alkaloids (Cyclohexane: Chloroform: Diethyl amine 5:4:1) } \\
\hline Sample extract & No. of spots & $\boldsymbol{R}_{f}$ value & Inference \\
\hline AMME & 1 & 0.511 & Protropin derivatives \\
\hline \multirow[b]{2}{*}{ DSME } & \multirow[b]{2}{*}{2} & 0.13 & Scopolamine \\
\hline & & 0.48 & Scopoline derivatives \\
\hline \multirow[b]{2}{*}{ PZME } & \multirow[b]{2}{*}{2} & 0.37 & Plumbogin \\
\hline & & 0.23 & Napthaquinone derivatives \\
\hline \multicolumn{4}{|c|}{ Tannins (Chloroform: Ethyl acetate: Acetic acid 50:50:10) } \\
\hline \multirow{3}{*}{ AMME } & \multirow{3}{*}{3} & 0.48 & Ferulic acid \\
\hline & & 0.57 & Cinnamic acid \\
\hline & & 0.71 & Cinnamic acid derivatives \\
\hline \multirow[t]{4}{*}{ DSME } & \multirow[t]{4}{*}{4} & 0.76 & Cinnamic acid derivatives \\
\hline & & 0.53 & Ferulic acid \\
\hline & & 0.25 & Paragallol \\
\hline & & 0.68 & Cinnamic acid derivatives \\
\hline PZME & 1 & 0.60 & Cinnamic acid derivatives \\
\hline \multicolumn{4}{|c|}{ Phenol/Flavonoid (Toluene: Ethyl acetate: Formic acid 36:12:5) } \\
\hline \multirow[t]{3}{*}{ AMME } & \multirow[t]{3}{*}{3} & 0.56 & Ferulic acid \\
\hline & & 0.77 & 6-Hydroxy flavones \\
\hline & & 0.88 & Flavone \\
\hline \multirow[t]{5}{*}{ DSME } & \multirow[t]{5}{*}{5} & 0.46 & 7-hydroxy flavone \\
\hline & & 0.56 & Ferulic acid \\
\hline & & 0.67 & 6-Hydroxy flavones \\
\hline & & 0.70 & 6-Hydroxy flavones derivatives \\
\hline & & 0.88 & Flavones \\
\hline \multirow[t]{2}{*}{ PZME } & \multirow[t]{2}{*}{2} & 0.67 & 6-Hydroxy flavones \\
\hline & & 0.70 & 6-Hydroxy flavones derivatives \\
\hline
\end{tabular}

Synergistic free radical scavenging activity of PHME

The results of the free radical scavenging activity of PZME, DSME, AMME and PHME tested by the DPPH method are depicted in Table 3 . All test samples were found to exhibit increase in percentage inhibition with increase in concentration at $\lambda \max 517 \mathrm{~nm}$. On the other hand, the comparative antioxidant activity among the test samples clearly revealed the combined synergistic effect of PHME, at the same concentration level selected for individual extract (PZME, DSME and AMME) with maximum $\%$ inhibition of $82.79 \%$ at $8 \mathrm{mg} / \mathrm{ml}$ as compared to standard ascorbic acid $(92.92 \%)$ as a standard antioxidant. The order of the antioxidant activity of test samples was found to be in order of PHME $>$ PZME $>$ AMME $>$ DSME.

Table 3: Synergistic antioxidant effect of polyherbal methanol extracts (PHME)

\begin{tabular}{|c|c|c|c|c|}
\hline \multirow{2}{*}{ Sample } & \multicolumn{4}{|c|}{$\%$ inhibition at different concentration } \\
\hline & $2 \mathrm{mg} / \mathrm{ml}$ & $4 \mathrm{mg} / \mathrm{ml}$ & $6 \mathrm{mg} / \mathrm{ml}$ & $8 \mathrm{mg} / \mathrm{ml}$ \\
\hline Ascorbic acid & $\begin{array}{c}63.84 \pm 1.263 \\
\mathrm{~b}^{* * * * *}\end{array}$ & $\begin{array}{l}67.59 \pm 0.304 \\
b^{* * *}\end{array}$ & $\begin{array}{l}87.26 \pm 1.909 \\
b^{* * * * *}\end{array}$ & $\begin{array}{l}92.92 \pm 0.790 \\
b^{* * * *}\end{array}$ \\
\hline PZME & $\begin{array}{l}20.52 \pm 0.397 \\
\mathrm{a} * * * * \\
\mathrm{~b}^{* * * * *}\end{array}$ & $\begin{array}{l}56.77 \pm 0.447 \\
a^{* * * *} \\
b^{*}\end{array}$ & $\begin{array}{l}57.82 \pm 0.599 \\
\mathrm{a}^{* * * *} \\
\mathrm{~b}^{* * * *}\end{array}$ & $\begin{array}{l}74.13 \pm 0.520 \\
\mathrm{a} * * * * \\
\mathrm{~b} * * * *\end{array}$ \\
\hline DSME & $\begin{array}{l}17.09 \pm 1.064 \\
\mathrm{a} * * * * \\
\mathrm{~b}^{* * * *}\end{array}$ & $\begin{array}{l}44.44 \pm 0.150 \\
\mathrm{a} * * * * \\
\mathrm{~b} * * * *\end{array}$ & $\begin{array}{l}47.77 \pm 1.611 \\
\mathrm{a} * * * * \\
\mathrm{~b}^{* * * *}\end{array}$ & $\begin{array}{l}75.35 \pm 1.267 \\
\mathrm{a} * * * * \\
\mathrm{~b} * * * *\end{array}$ \\
\hline AMME & $\begin{array}{l}13.77 \pm 0.728 \\
\mathrm{a} * * * * \\
\mathrm{~b} * * * *\end{array}$ & $\begin{array}{l}45.88 \pm 0.193 \\
\mathrm{a} * * * * \\
\mathrm{~b} * * * *\end{array}$ & $\begin{array}{l}61.93 \pm 0.220 \\
\mathrm{a} * * * * \\
\mathrm{~b}^{* * * *}\end{array}$ & $\begin{array}{l}78.64 \pm 0.939 \\
\mathrm{a} * * * * \\
\mathrm{~b} *\end{array}$ \\
\hline PHME & $\begin{array}{l}40.43 \pm 0.872 \\
a^{* * * *}\end{array}$ & $\begin{array}{l}61.10 \pm 0.728 \\
a^{* * *}\end{array}$ & $\begin{array}{l}71.78 \pm 1.599 \\
a^{* * * *}\end{array}$ & $\begin{array}{l}82.79 \pm 1.718 \\
a^{* * * *}\end{array}$ \\
\hline
\end{tabular}

All values are represented as mean \pm SEM, $n=3$ for each group, Data were analyzed by two-way ANOVA, for each bacterial strain, followed by Dunnett's multiple comparisons test Multiple Comparisons Test, $* * * * \mathrm{p}<0.0001 * * * \mathrm{p}<$ $0.001, * * \mathrm{p}<0.01,{ }^{*} \mathrm{p}<0.1$. (a) Denotes significant difference as compared to ascorbic acid (standard drug) and (b) denotes significant difference as compared to test drug PHME. 


\section{DISCUSSION}

Phytochemical screening of the PHME showed the presence of triterpenoids, tannins, glycosides, flavonoids, polyphenols, carbohydrates, alkaloids etc. All these classes of compounds have good antioxidant potential and their effects on human nutrition and health are significant ${ }^{20-22}$.

The FTIR spectrum of PZME, AMME and DSME showed peaks at $3408.82 \mathrm{~cm}^{-1}, 3143.23 \mathrm{~cm}^{-1}$ and $3409.99 \mathrm{~cm}^{-1}$ respectively corresponding with the hydroxyl groups of polyphenols while peaks at $1653.61 \mathrm{~cm}^{-1}, 1603.51 \mathrm{~cm}^{-1}$ and $1660.03 \mathrm{~cm}^{-1}$ corresponds to carbonyl $(\mathrm{C}=\mathrm{O})$ groups. Sharp peaks at $1004.05 \mathrm{~cm}^{-1}$, $1000.81 \mathrm{~cm}^{-1}$ and 1002.16 are assigned to alcohols (CO) while peaks at $2851.78 \mathrm{~cm}^{-1}, 2849.44 \mathrm{~cm}^{-1}$ and $2847.88 \mathrm{~cm}^{-1}$ showed the presence of carboxylic acid group. The majority of the peaks were broad and overlapped indicating the presence of a mixture of chemical constituents. The functional group may mask the other groups at a similar wave number. Peaks observed at $1653.61 \mathrm{~cm}^{-1}, 1603.51 \mathrm{~cm}^{-1}$ and $1660.03 \mathrm{~cm}^{-1}$ corresponds to prominent flavonoids like quercetin and rutin which could be due to aromatic ketonic carbonyl stretching $^{23}$.

Many plant extracts have been shown to possess potent free radical scavenging activity that due to the combinatorial effect of polyphenolics and flavonoids. The flavonoids and polyphenols have the ability to induce human protective enzyme systems and are known to be a potent source of antioxidants. They exhibit protective effects against many infectious and degenerative diseases such as bacterial and viral diseases, cardiovascular diseases, cancers and other agerelated diseases ${ }^{24}$. Phytochemical characterization of DSME, AMME and PZME revealed the presence of Rutin (flavonoid) and Gallic acid (phenolic acid). The vicinyl dihydroxyl groups in Rutin and its metabolites were shown to affect the ability of phenols to inhibit iron and copper-catalyzed production of initiating radical species. Thus, it was more likely to scavenge radical by inhibiting glucose autoxidation ${ }^{25}$. Among various polyphenols, Gallic acid (GA) (3,4,5-

\section{REFERENCES}

1. Halliwell B. Oxidative stress and neurodegeneration: where are we now? Journal of Neurochemistry. 2006; 97(6):1634-58.

2. Ferguson LR. Chronic inflammation and mutagenesis. Mutation Research/Fundamental and Molecular Mechanisms of Mutagenesis. 2010; 690(1):3-11.

3. Morales G, Paredes A, Sierra P, Loyola LA. Antioxidant activity of $50 \%$ aqueous-ethanol extract from Acantholippia deserticola. Biological research. 2008; 41(2):151-5.

4. Brahmachari G, Gorai D, Roy R. Argemone mexicana: chemical and pharmacological aspects. Revista Brasileira de Farmacognosia. 2013; 23(3):559-67.

5. Gaire BP, Subedi L. A review on the pharmacological and toxicological aspects of Datura stramonium L. Journal of integrative medicine. 2013; 11(2):73-9.

6. Rana AC. Plumbago zeylanica. A Phytopharmacological review. International Journal of Pharmaceutical Sciences and Research. 2011; 2(2):247.

7. Meena AK, Bansal P, Kumar S. Plants-herbal wealth as a potential source of ayurvedic drugs. Asian Journal of Traditional Medicines. 2009; 4(4):152-70. trihydroxybenzoic acid) has been shown to possess strong antioxidant activities in many studies and was also found to exhibit both antioxidants as well as prooxidant characteristics ${ }^{26}$.

The thin layer chromatography of the methanolic extract (DSME, PZME and AMME) selected for polyherbal combination revealed presence of alkaloid, tannins, polyphenol and flavonoid compounds ${ }^{27}$. PHME was found to possess synergistic antioxidant activities as compared to individual constituents (DSME, PZME and AMME) and could be potentially used to potentiate tissue repair and rejuvenation process ${ }^{28-29}$. In living systems, free radicals are constantly generated and can cause extensive damage to tissues and biological molecules leading to various diseases. Many synthetic drugs can protect against oxidative damage, but, because of their adverse side effects an alternative solution is to consume natural antioxidants through food supplements and traditional medicine ${ }^{30}$. Since ancient times, herbal or plant-based medicines have served as a platform for the prevention and cure of diseases and many constituents of these natural sources are yet to be explored. This has enlightened scientists to establish newer compounds alone or in combination of the herbal source having antioxidant activity to treat/mitigate oxidative stress induced pathogenesis for a number of diseases.

\section{CONCLUSION}

The polyherbal with its high antioxidant efficacy indicates that polyherbal supplement would become a significant source of natural antioxidants, helpful in preventing and mitigating harmful damage caused by oxidative stress.

\section{ACKNOWLEDGEMENT}

The author would like to thank the Department of Pharmaceutical Sciences, Mohan Lal Sukhadia University, Udaipur, for providing all the necessary facilities. The financial support received from the University Grants Commission, New Delhi, in the form of Rajiv Gandhi National Fellowship is gratefully acknowledged.

8. Singh MK, Pandey A, Sawarkar H, Gupta A, Gidwani B, Dhongade H, Tripathi DK. Methanolic extract of Plumbago Zeylanica-a remarkable antibacterial agent against many human and agricultural pathogens. Journal of Pharmacopuncture. 2017; 20(1):18.

9. Sharma RA, Sharma PA, Yadav AN. Antimicrobial screening of sequential extracts of Datura stramonium L.International Journal of Pharmacy and Pharmaceutical Sciences. 2013; 5(2):401-4.

10. Dash GK, Murthy PN. Evaluation of Argemone mexicana Linn. Leaves for wound healing activity. Journal of Natural Product and Plant Resources. 2011; 1(1):46-56.

11. Khandelwal KR. Practical Pharmacognosy Techniques and Experiments, Nirali Prakashan, $22^{\text {nd }}$ Edition 2005.

12. Madaan R, Bansal G, Kumar S, Sharma A. Estimation of total phenols and flavonoids in extracts of Actaea spicata roots and antioxidant activity studies. Indian journal of Pharmaceutical Sciences. 2011; 73(6):666. 
13. Svendsen AB. Chromatography of Alkaloids, Part A: ThinLayer Chromatography. Journal of Chromatography Library, Volume 23A. Elsevier Science \& Technology; 1983.

14. Sharma OP, Bhat TK, Singh B. Thin-layer chromatography of gallic acid, methyl gallate, pyrogallol, phloroglucinol, catechol, resorcinol, hydroquinone, catechin, epicatechin, cinnamic acid, p-coumaric acid, ferulic acid and tannic acid. Journal of Chromatography A. 1998; 822(1):167-71.

15. Medić-Šarić M, Jasprica I, Smolčić-Bubalo A, Mornar A. Optimization of chromatographic conditions in thin layer chromatography of flavonoids and phenolic acids. Croatica Chemica Acta. 2004; 77(1-2):361-6.

16. Srivastava AK, Nagar H, Srivastava R, Ahirwar V, Chandel HS. Evaluation of antitussive and anti-asthmatic activity of Tabernaemontana divaricata (L.) R. Br. Ex Roem. and Schult. AYU (An international quarterly journal of research in Ayurveda). 2016; 37(3):256.

17. Ayres GH. Evaluation of accuracy in photometric analysis. Analytical Chemistry. 1949; 21:652-657.

18. Sloane HJ, William SG. Spectrophotometric accuracy, linearity and adherence to Beer's law. Applied Spectroscopy. 1977; 31:25-30.

19. Otohinoyi DA, Ekpo O, Ibraheem O. Effect of ambient temperature storage on 2, 2-diphenyl-1-picrylhydrazyl (DPPH) as a free radical for the evaluation of antioxidant activity. International Journal of Biological and Chemical Sciences. 2014; 8(3):1262-1268.

20. Chaudhary D, Srivastava R, Kumar Srivastava A, Kotiya A. Wound Healing Activity of Hydro-alcoholic Extract of Cinnamomum nitidum Blume (Lauraceae) in Wistar Albino Rats. Current Traditional Medicine .2016; 2(2):134-45
21. Havsteen BH. The biochemistry and medical significance of the flavonoids. Pharmacology and Therapeutics. 2002; 96(23):67-202.

22. Gumul D, Korus J, Achremowicz B. The influence of extrusion on the content of polyphenols and antioxidant/antiradical activity of rye grains (secale cereale 1.). Acta Scientiarum Polonorum Technologia Alimentaria. 2007; 6(4):103-11.

23. Sri KV, Kondaiah A, Ratna JV, Annapurna A. Preparation and characterization of quercetin and rutin cyclodextrin inclusion complexes. Drug Development and Industrial Pharmacy. 2007; 33(3):245-53.

24. Pandey MM, Khatoon S, Rastogi S, Rawat AK. Determination of flavonoids, polyphenols and antioxidant activity of Tephrosia purpurea: a seasonal study. Journal of Integrative Medicine. 2016; 14(6):447-55.

25. Yang J, Guo J, Yuan J: In vitro antioxidant properties of rutin. LWT-Food Science and Technology. 2008; 41(6):1060-6.

26. Badhani B, Sharma N, Kakkar R. Gallic acid: a versatile antioxidant with promising therapeutic and industrial applications. RSC Advances 2015; 5(35):27540-57.

27. Scartezzini P, Speroni E. Review on some plants of Indian traditional medicine with antioxidant activity. Journal of Ethnopharmacology. 2000; 71(1-2):23-43.

28. Aslam MS, Ahmad MS, Mamat AS, Ahmad MZ, Salam F. Antioxidant and wound healing activity of polyherbal fractions of Clinacanthus nutans and Elephantopus scaber. Evidencebased Complementary and Alternative Medicine. 2016; 2016.

29. Talekar YP, Apte KG, Paygude SV, Tondare PR, Parab PB: Studies on wound healing potential of polyherbal formulation using in vitro and in vivo assays. Journal of Ayurveda and Integrative Medicine. 2017; 8(2):73-81.

30. Kajaria DK, Gangwar M, Sharma AK, Tripathi YB, Tripathi JS, Tiwari S. Evaluation of in vitro antioxidant capacity and reducing potential of polyherbal drug-Bhārangyādi. Ancient science of life. 2012; 32(1):24. 